\title{
內臟轉錯症患者に發生せる十二指腸結核の一例
}

\section{A Case of Duodenal Tuberculosis happened to complete Inversio viscerum.}

\begin{tabular}{|c|c|c|}
\hline 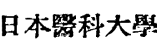 & 行德内科教室 & \\
\hline 醫學博士 & $\begin{array}{cc}\text { 吉 } & \begin{array}{c}\text { 田 } \\
\text { Yoshida }\end{array}\end{array}$ & $\begin{array}{c}\text { 弘 } \\
\text { Kōhei }\end{array}$ \\
\hline 罍學士 & $\begin{array}{l}\text { 寺 } \quad \text { 本 } \\
\text { Teramoto }\end{array}$ & $\begin{array}{l}\text { 雪 } \\
\text { Yukio }\end{array}$ \\
\hline 醫學士 & $\begin{array}{l}\text { 大 竹 作 } \\
\text { Otake Sakuz }\end{array}$ & 左 衛 \\
\hline
\end{tabular}

消化器結核仕屡々結核性聅患殊飞肺結核に續 發し, 其の部位も廻腸下部, 盲腸部が最も多く 侵され胃及び十二指腸部の侵されるのは極めて 稀である。それで胃結核は Barkhausen の 報告以來可なり多數の症例報告があり, 我國に 於ても肥田の結核性胃潰㾴の剖檢的報告龙以て 嗃矢とし, 爾來三田, 關, 柳, 熊野等の症例報 告があるが沿相當稀有なものとされて居る。又 諸家の統計には可成りの高低の差活るも大體 飞於て全結核屍の約 $1 \%$ 內外飞相當するもの之 思はれる。更に十二指腸結核の報告例は之より 遙か儿尠くGossmann が十二指腸の定型的結 核性潰瘍飞就いて報告して以來，本邦では黑丸 が剖檢的江之確認し，岩井，木塚，國井等其 の症例報告は僅か比數ふるげけに過ぎない。而 して此等恠告されたるものもその大部分は病理 解剖學的飞發見されたもので，臨床的汇診斷觀 察されたもの極めて少ない。即ち本症は甚だ 稀なもので西る上に生前にとれと診斷する事汇 頗る困難なものと云は秝ばならない。蕬行報告

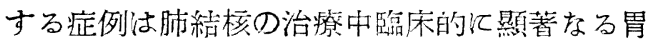
症狀を示した十二指腸結核で剖檢飞依りて之を 確認し得た一例である。

姓名 19 歲 男子

入院 1949 年 6 月 1 日

患者は完全內獩轉錯症であつて胸部，腹部の 諸臟器洼全部左右轉錯して居た事厸入院當時か ら分つて居たが空が十二指腸結核と直接の關係 があつたものでは西るまい。此の患者は昭和 23 年10月頃より喛嗽，喀痰声り，翌年 3 月保健所
で健康診斷を求めた所肺結核を診斷され，以來 右側氣胸療法を施行中であつたが, 最近 38 度 前後の弛張性發熱を見るに至つたので當內科に 入院したものである。

現症及び經過：體格中等大，筋肉及び皮下脂 肪組織の發育不良にして, 贏瘦せる無力型の男 子, 顏貌蒼白で西る。胸蔚讷左右對象的, 肋 間陷沟して肋骨は著明飞見元る。心臟は前記の 如く內臟轉錯症で西るので右の胸飞認められ る。郎ち心尖仙右側第四肋間腔飞右乳線より一 横指內側飞左境, 界江右眴骨緣飞西る。第二肺 動脈音は元進して居る。肺臟は左側上部は前後 とも濁音在呈し，呼氣延長し，尖錦である。且 つ多數の水泡音を聞き, 右側下部にも多少聞き 得た。肺肝境界は左側第五肋間腔で, 胃部の政 音俚右側肋弓下に證明出來た。

腹部を視ると一般に陷沟して居るが, 上腹部 は稍々緊張して居る。肝は左側肋弓下にわうかか 飞觸れ得るが，聘，腎仙觸知する事が出來ない 下肢には浮腫なし。

尿屎に著變标く, 血液检査では中等度の貧血 が西つて, 赤沈速度 1 時間值 97 籷であつた。

入院 てケ月の間最高 38 度乃至 39 度に及ぶ 弛張性發熱が西り, 咳嗽著しく, 喀痰は膿樣粘 液性で結核菌憸查は常に陽性で「ガフキー」3 〜5號であつた。

患者は入院當初から食思缺乏が目について居 たが，6月下旬頃上り心窝部疼痛を訴人る樣に なり，時には右心窩部て鴙卵大の腫瘤を觸れた 事も西つたが間もなく消失する。恐らく胃の緊 
縮したものと思溹れる。疼痛の强度も種々樣々 で時には屯服で文或る時飞は鎮痛劑の注射をも 必要とした。疼痛は主として起床時或は室腹時 に起つたが，食事とは無關係に起る事も西つ た。腹痛は甚だ項固で種々投藥，手當等を代一 て見るも餘り効果的でなく後には嘔氣を伴い吐 物を見た事も西つたので患者は食物攝取を差し 控八る事さへあつた。斯くして症彇况一進一退 して居たが, 同年 10 月頃より腹部膨滿感を訴 一且つ一般に壓痛强まり, 特汇简部及び左右季 助部飞於て甚しかつた。下腹部は一般汇鼓腸を 呈するも該部の壓痛仙輕度であつた。更に 12 月頃から慢性の下㾥等腸結核の症狀も現すに至 b, 且つ同時江燕下痛, 毊音嘶嗄等喉頭結核の 症狀現はれるに至つて襄弱急速に增加し翌年 1 月 10 日逐に鬼籍に上つたものである。

6 月末以來上腹痛, 食思不振, 嘔心等現はれ 如何なる手當も効果なく數ケ月も持續するので 胃䊅核ではないかなど云ひながら 10 月には胃 の檢查其他飞就て貫驗在行つた。

胃液檢查: G. Katsch の法に依る胃液の分 劃採取法により檢查した。前液 15 少しく粘 液を混一多少白濁す。遊離監酸なく總酸度 6 度 試驗液は投與後10分をきに胃液を採取したが, メチレン毒の色は50分，1時間以後は消失し， 酸度を 40 分より 120 分間に高まり遊離監酸 8 〜 10, 總酸度 15 18 の間で大體胃酸減弱症と 云ふ事が出來た。血液を混ぜしものく, 乳酸 反應当常沉陰性で西つた。

胃のX楾檢㚗：「バリウム」を與へて胃の檢 查を行つたが, 胃の位置も右側沉りり, 左右轉 錯して居る事が登明出來た。其の形態に異常な く運動の狀態も犬體正常である。胃部にも十二

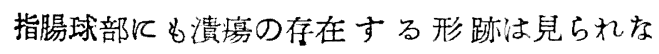
い。但し此の竄洒仙解剖する前約 3 ケ月のもの で腹痛も未だ比較的輕微の頃のものであつた。

自律种經機能檢查：アドレナリン，アトロピ ン,ピロカルピンを存ひ診㣎したが，ピロカル ピンイは極めて敏感で, 强度の發汗, 脈搏增加 頌面潮紅, 胃腸運動立進在起し, 腹痛在件つて 下涮數回を來した。殊て流诞法著明で 1 時間 60 cc 火及び迷走种經祭張在示した。血結値 95 $\mathrm{mg} / \mathrm{dl}$. 殘餘䇪素 $36.0 \mathrm{mg} / \mathrm{dl}$.

以上青結核或汢單純性の潰場などを考人なが らも之在確實:方證據も出ないので普通の處 置を續けて居たが死後の剖檢によつて次の事實 が明かとなつた。

病理解剖學的所見 :

兩側肺結核 (宾洞形成), 腸結核及ひ喉頭結核 があつたが，此等の詳細汢省略し胃及び十二指 腸の變化汇就て述べる。

胃の粘膜面汁一般江腫脹溷濁し, 污穢灰白色 の粘秱なる物質を以て蔽はれ，一見して慢性胃 炎の狀存呈す。

幽門部に注米粒大の潰瘍 1 個あり邊緣不正鋸

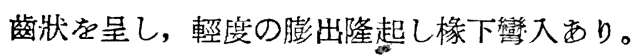
底面は稍々不平等にして污穢淡黄色を呈す。

十二指腸沾粘膜一般に貧血性にして特に幽門 輪より十二指腸始部にかけて 4 ケの米粒大の潰 瘍を見る。性狀は大體に於て胃部の潰瘍と同じ く何れも邊橡不正鋸苜狀を呈し, 底面は污穢な る粘稠物質を以て蔽はれて, 輕度の橡下彎入を認 めた。

\section{組織的所見:}

十二指腸潰廈部：一般飞潰痘は粘膜下層飞達

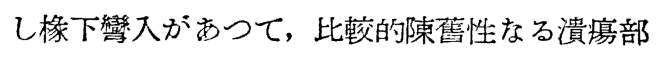
に於ては潰瘍底の一部は乾酷變化に陷り, 周邊 部郎ち橡下彎入部に於ては結核性細胞浸潤著明 てして, 類上皮細胞及び小圆形細胞多數飞認め られた。又他の比較的新らしい潰境部に於ては 殊飞橡下彎入部飞細胞浸潤甚しく, 粘膜筋層の 下部に沿つて周圍に擴延する傾问が西り, 該部 には「ラングハン」氏巨態細胞をも認めた。潰 㾤周圍粘膜及び十二指腸腺部にも一般に細胞浸 潤强く腺組織像明らかならず。

漿膜は多少肥厚したるも結節乃至細胞浸潤等 見られずして殆んぞ正常に近し。結核菌染色に 於ては潰瘍部汇結核菌を證明出來なかつた。

ただ肉眼的汇は結核性と思伒た胃幽門部潰 疸は結核性病霆を呈せずして寧ろ單純性潰㾤の 樣に思はれた。

晌空腸下部より䞟腸末端部にかけで少しく 
大なる潰揚在更に又上行結腸には拇指頭大のも の蹯在するの認めた。

以上肺結核患者飞生前㙷著な胃症狀を呈した ものに剖見飞低り始めて十二指腸結核の診斷を 下し得たるものであるが本例汇於ては腹部淋巴 腺及び附近の蕣膜飞變化の少かつた事, 腸の上 部に潰嫁の多かつた事, 殊飞喀咨には常に多數 の結核菌を檢出し得た事などから考へて恐らく

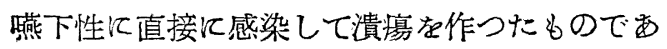
る樣に思ふ。

(本論文要旨は昭和 25 年 7 月 1 日第 34 回 日本纣科學會關東地方會に於て發表した。）

閤筆に臨み終始御郎切なる校閱を賜りたる行
德敎授に對し滿腔の謝意を表するものである。

\section{要 文 献}

肥田: 東京醫學會雜誌, 第 2 能, 9 躆 463 頁 (明治 21件)

關: 絬核, 第 5 㣞, 1206 頁 (炤和 2 年)

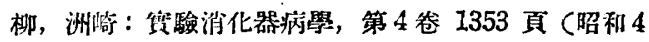
年)

木塚, 國半: 診断と治療, 17 卷, 3 號 (昭和 5 年)

黑丸: 結核, 9 邑, 5 號, 749 頁 (昭和 6 年)

熊野：ダレンツゲビート，6，10號，1218頁(昭和 7 年)

小池：日本队科學會雜誌，24兊， 4 號， 430 面 (炤和 11年)

岩井：日本臨床結核，1兊，4號，419 面(昭和 15 年)

\section{膀 胱 全 剝 脫 症 例}

A Case of Exfoliatio Vesicae Totalis

日本距科大學 泌尿器科教宣 (主任 北川 湜㸚授)

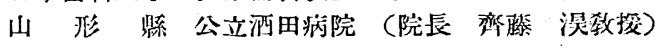

皮旃泌器科醫長野崎

Nozaki Minoru

\section{緒言}

膀胱炎には種↔の分類法が西り，色及の名稱 が附计られている。䏩胱剥脫もその一つで西つ $\tau$, 剝脫性膀胱炎の一亞型之为云ふ可く, 獨立 疾患を意味するよりも察万形容的飞使用せられ 膀胱の重症化膿性炎症のために廣沉な膀胱粘膜 面が剝脫して來るものと對する病理解剖的肉眼 所見或は膀胱鏡所見によつてつけられた病名で 西る。

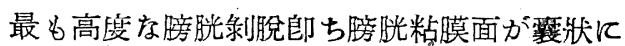
完全剝脫せる報告汢文献上泌尿器科方面儿於て はEsau の 2 例が見出されたに過ぎない。

私は膀胱結核にて治療中の患者が重篤な膀胱 炎症狀存現はし，終江完全尿閉湶陷り，止むな く手術的飞膀胱を切開して, 初めて膀胱粘膜が 全面的に且つ同時的に剥離を起こしたために起 つた尿閉である事を識り，ここに報告する。

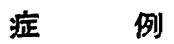

患者 19 歲 今 學生

初診 昭和 23 年 7 月 24 日

初診時主訴 高熱, 僣怠, 尿意頻數, 放尿終

\section{末痛の增大}

家族歷 兩親健在 祖父 57 歲胃癌にて死亡 祖母 75 歲腦溢血のため死亡, 同胞 6 名中 1 名 肺結核にて療養中, 他は健在

既往症 生來健康著患を識らなかつたが, 18 歲の時，右腎結核兼結核性膀胱炎の診斷のもと 亿右腎剔出存施行し, 爾來膀胱結核治療のため に醫治を受けつ>西つた。

現病歷 昭和 23 年 7 月 23 日夕方上り全身 供怠, 惡心, 輕任の頭痛があり, $39^{\circ}$ の發熱在 みた，24 日 \&同樣の症狀繼結したため, 酒田 病院皮膚泌尿器科外來在訪れた。

現 症體格, 笑食共飞中等度, 顏色蒼白, 顏貌稍々無氣力狀, 可視粘膜及び舌に異常を認 めない。淋巴腺の異常腫脹在觸れない。脈膊正 常, 體溫 $38^{\circ}$ 打聽診上胸部飞變化存認めず, 腹 部は平坦柔軟で西つて, 緊張, 異常抵抗はな い。右腎部には腎别創般痕存認める他異常はな く, 左腎部に壓痛なく, 僅か、下腹部㻺迫によ り不快感を訴へた。膀胱壁は觸診し得ない。 